\title{
Identifikasi Pasar, Komoditas, dan Margin Bersih Usaha Pasar Rumput di Wilayah Pembibitan Sapi PO Kebumen Kabupaten Kebumen
}

\section{Market Identification, Commodities and Net Profit Margin of Grass Market in the PO Kebumen Cattle Breeding Cluster at Kebumen District, Central Java}

\author{
N. Nuraeni* dan M. F. I. Aryadi \\ Program Studi Peternakan, Universitas Ma'arif Nahdlatul Ulama Kebumen1,2 Jalan Kusuma No. 75 \\ Kebumen - Indonesia \\ *Corresponding E-mail: nunur.umnu@gmail.com \\ (Diterima: 6 September 2019; Disetujui: 22 November 2019)
}

\begin{abstract}
ABSTRAK
Penelitian bertujuan untuk mengungkapkan tiga hal yaitu jumlah pasar rumput, jenis rumput dipasaran, dan margin bersih dari usaha. Pasar rumput muncul di wilayah pembibitan Sapi PO Kebumen karena keterbatasan waktu peternak mencari rumput dan pertambahan jumlah ternak. Waktu penelitian adalah dari Juli sampai dengan September 2019. Metode penelitian dilakukan secara survei dengan mengambil seluruh pemilik pasar rumput sebagai responden. Analisa data dilakukan dengan deskriptif kuantitatif dan statistik sederhana serta net profit margin (NPM). Hasil penelitian menunjukan bahwa wilayah pembibitan sapi PO Kebumen meliputi enam kecamatan. Jumlah pasar rumput di enam kecamatan Wilayah Pembibitan Sapi PO Kebumen sebanyak 126 orang pemilik pasar rumput. Komoditas pakan yang dijual di pasar rumput terdiri dari tujuh jenis, yatu: jerami padi, rumput gajah, rumput gajah odot, jerami kacang tanah (rendeng), rumput alam, kangkung, dan dedak padi. Pakan yang paling banyak diperjual belikan adalah jerami padi. Rata-rata pendapatan usaha pasar rumput sebesar Rp.418,110.39/hari dengan rata-rata Net Profit Margin sebesar $13.11 \%$.
\end{abstract}

Kata kunci: margin bersih, pasar rumput, wilayah pembibitan Sapi PO Kebumen

\begin{abstract}
The research aims to reveal three things, namely the number of grass markets, the types of grass on the market, and the net margins of the business. The grass market appears in the PO Kebumen Cattle breeding area due to limited time for farmers to look for grass and increase the number of cattle. The research time is from July to September 2019. The research method was conducted in a survey by taking all the grass market owners as respondents. Data analysis was performed with quantitative descriptive and simple statistics and net profit margin (NPM). The results showed that the area of PO Kebumen cattle breeding covered six districts. The number of grass markets in the six districts of the Kebumen Cattle Breeding District is 126 grass market owners. Feed commodities sold in the grass market consist of seven types, namely: rice straw, elephant grass, elephant odot grass, peanut straw (rendeng), natural grass, kale, and rice bran. The most-traded feed is rice straw. The average income of the grass market business is Rp.418,110.39 / day with an average Net Profit Margin of $13.11 \%$.
\end{abstract}

Keywords: grass market, PO Kebumen cattle breeding area, net margins 


\section{PENDAHULUAN}

Peternak Sapi PO Kebumen tidak hanya bermata pencaharian sebagai peternak, namun juga sebagai petani pedagang, tukang dan pegawai (guru/dinas). Berdasakan penelitian Nuraeni dan Aryadi (2017) yang melakukan wawancara terhadap 438 responden peternak, menyatakan bahwa seluruh peternak yang menjadi responden baik di kelompok maupun di masyarakat menjadikan usaha pembibitan sapi menjadi usaha sampingan, sebagian besar pekerjaan utamanya adalah petani dan sebagian kecil ada yang menjadi pedagang dan tukang. Apabila disaat musim tanam padi dan tanaman palawija peternak akan lebih mengutamakan pekerjaan bertaninya dibandingkan memelihara ternak, hal ini menjadikan pihak lain (pedagang) berkesempatan membuka peluang usaha yaitu mendirikan pasar rumput. Pada saat musim tanam peternak lebih mengutamakan pekerjaan bertaninya sehingga dalam penyediaan pakan lebih sering membeli di pasar rumput dari pada mencari (ngarit). Khusus pada peternak yang juga merupakan pegawai, pedagang atau tukang, dalam penyediaan pakan ternak setiap saat lebih banyak membeli karena ketiadaan waktu untuk mencaripakan.

Kondisi ini membuat banyaknya pasar rumput bermunculan khususnya di wilayah pembibitan. Pasar rumput dianggap mata pencaharian baru yang menguntungkan. Berdasarkan penelitian Sudrajad dan Subiharta (2013) pakan yang biasa digunakan oleh peternak sapi PO di Kabupaten Kebumen berupa rumput lapang, rumput unggul, jerami padi, jagung dan diberi pakan tambahan berupa singkong atau bekatul.

$$
\text { Menurut Soedardjat (2001), }
$$
kebijakan pengembangan peternakan yang dikembangkan di suatu daerah harus disesuaikan dengan potensi pakan lokal yang ada di daerah tersebut. Dalam rangka memenuhi kebutuhan bahan baku pakan lokal, baik kuantitas maupun kualitas sebenarnya telah banyak dicobakan pemberian bahan baku pakan lokal dari limbah pertanian dan limbah industry pertanian dengan sentuhan teknologi terapan ke ternak. Hal ini disebabkan karena limbah pertanian seperti jerami padi, jagung dan pucuk tebu umumnya mempunyai kualitas yang rendah (Sinurat, 2001).

Potensi Pakan di daerah Jawa Tengah $52,57 \%$ berasal dari limbah pertanian, sedangkan dari rumput lapang $27,06 \%$ dan $20,37 \%$ berasal dari rumput unggul Potensi pakan yang berasal dari limbah pertanian tersebut, 37,36\% berasal dari jerami padi, $51,31 \%$ berasal dari jerami jagung, 2,81\% berasal dari daun ketela pohon, $0,69 \%$ berasal dari daun ketela rambat, $3,14 \%$ berasal dari jerami kedelai, $2,35 \%$ berasal dari daun kacang tanah, 2,32\% berasal dari daun tebu dan $0,02 \%$ berasal dari daun-daunan lain (Tabrani et al., 2004).

Sofian (2001) menyatakan bahwa pakan lokal yang bersumber dari limbah industri pertanian dan limbah pertanian mempunyai kendala seperti kadar airnya tinggi, kandungan protein rendah, dan adanya zat anti nutrisi selain itu juga keragaman dalam komposisi kandungan zat gizi bahan baku pakan lokal sangat besar koefisien variasinya $(>20 \%)$. Sumbangan bahan pakan yang berasal dari limbah pertanian ini cukup besar maka perlu dilakukan upaya pengolahan limbah pertanian baik secara fisik, kimiawi, biologi atau kombinasi diantaranya. Berdasarkan penelitian Tabrani et al. (2004), hijauan pakan ternak yang digunakan oleh peternak di Kabupaten Kebumen terdiri dari 53,8\% limbah pertanian, 7,8\% rumput lapangan dan $2,1 \%$ rumput unggul.

Berdasarkan uraian sebelumnya, penelitian akan mengungkapkan mengenai: jumlah pasar rumput yang terdapat di Wilayah Pembibitan Sapi PO Kebumen Kabupaten Kebumen, keanekaragaman jenis rumput yang diperjual belikan di pasar rumput dan margin bersih dari usaha pasar rumput.

\section{METODE}

\section{Sasaran dan Lokasi Penelitian}


Sasaran penelitian adalah pasar rumput yang berada di wilayah pembibitan Sapi PO Kebumen. Lokasi penelitian adalah enam kecamatan yang merupakan wilayah pembibitan Sapi PO Kebumen yang terdiri dari : Kecamatan Puring, Petanahan, Klirong, Buluspesantren, Ambal dan Mirit yang dikenal juga dengan paling besar yang menjual rumput dengan volume paling banyak diantara pasar rumput lainnya di masing-masing kecamatan.

\section{Metode Penelitian}

Metode yang digunakan dalam penelitian ini adalah survei (wawancara) terhadap pemilik pasar rumput yang berada di wilayah pembibitan Sapi PO Kebumen. Untuk mengetahui jumlah pasar rumput dan keanekaragaman jenis rumput yang diperjualbelikan dilakukan dengan metode sensus, yaitu menghitung/ mendata seluruh pasar rumput di wilayah pembibitan Sapi PO Kebumen. Untuk mengetahui besar profit usaha pasar rumput dilakukan dengan purposive sampling yaitu menghitung profit pada pasar rumput yang paling besar yang menjual rumput dengan volume paling banyak diantara pasar rumput lainnya di masingmasing kecamatan.

\section{Variabel Penelitian}

Variabel yang diteliti adalah:

1. Jumlah pasar rumput

2. Keanekaragaman jenis rumput yang diperjualbelikan di pasar rumput

3. Profit usaha pasar rumput

\section{Metode Pengambilan Sampel}

Sampel wilayah dipilih dengan menggunakan metode purposive sampling yaitu wilayah Pembibitan Sapi PO Kebumen di enam kecamatan yang merupakan lokasi sentra Sapi PO Kebumen. Untuk mengetahui jumlah pasar rumput dan keanekaragaman jenis rumput yang diperjualbelikan di dilakukan dengan metode sensus yaitu mendata seluruh pasar rumput yang berada pasar rumput terbesar di masing-masing kecamatan dibantu petugas pembibitan Sapi PO Kebumen di masing-masing kecamatan yang diwadahi oleh organisasi ASPOKEB (Asosiasi Pembibit Sapi PO Kebumen).

$$
\text { Dilakukan deskripftif statistik }
$$
untuk mengetahui jumlah pasar rumput, keanekaragaman jenis rumput yang diperjualbelikan dan rata-rata profit usaha pasar rumput. Profit usaha pasar rumput dihitung dengan mengurangi penerimaan dengan pengeluaran. Kemudian untuk mengetahui Efektifitas dan efisiensi usaha pasar rumput dihitung NMP dengan rumus: (Net operating income) / (Net sales) x100.

Laba merupakan imbalan atas upaya perusahaan dalam menghasilkan barang dan jasa. Laba merupakan kelebihan pendapatan dari biaya dan merupakan hal paling penting dalam sebuah perusahaan (Suwardjono, 2008). Net Profit Margin (NPM) adalah rasio yang menunjukan kemampuan perusahaan dalam menghasilkan keuntungan bersih setelah dipotong pajak Semakin besar rasio NPM, maka dianggap semakin baik kemampuan perusahaan untuk mendapatkan laba yang tinggi (Alexandri, 2008).

\section{HASIL DAN PEMBAHASAN}

\section{Identitas Responden}

Responden dalam penelitian adalah pelaku usaha pasar rumput. Setelah dilakukan sensus di enam Kecamatan Wilayah Pembibitan Sapi PO Kebumen. Rata-rata umur pelaku usaha pasar rumput di enam kecamatan adalah 49,51 tahun, dimana pelaku usaha pasar rumput paling muda yaitu 26 tahun berada di Kecamatan Petanahan dan yang paling tua adalah 76 tahun berada di Kecamatan Buluspesantren. Kisaran umur pelaku usaha pasar rumput berada di usia produktif dan usia yang tidak produktif. Berdasarkan Undang-Undang No. 13 Tahun 2003 tentang Ketenagakerjaan, usia produktif berada pada kisaran 15-64 tahun (Tabel 1).

Rataan pengalaman lamanya menjalankan usaha pasar rumput yaitu 8,06 tahun. Rentang pengalaman menjalankan usaha pasar rumput cukup jauh dari yang 
Tabel 1. Profil pelaku usaha pasar rumput

\begin{tabular}{lccccccccc}
\hline \multirow{2}{*}{ Kecamatan } & Rataan & \multirow{2}{*}{$\begin{array}{c}\text { Umur } \\
\text { (th) }\end{array}$} & Usahalaman (th) & Pasar Rumput & Pekerjaan & Pasar Rumput & \multicolumn{5}{c}{ Pendidikan } \\
\cline { 7 - 10 } & & Utama (\%) & Pekerjaan & Sampingan (\%) & SD & SMP & SMA & S1 \\
\hline Puring & 52,25 & 7,45 & 40 & 60 & 45 & 20 & 30 & 5 \\
Petanahan & 47,29 & 12,30 & 33,33 & 66,67 & 62,5 & 33,33 & 4,17 & 0 \\
Klirong & 46,44 & 8,84 & 37,5 & 62,5 & 50 & 28,12 & 21,88 & 0 \\
Buluspesantren & 56,40 & 8,65 & 80 & 20 & 55 & 35 & 10 & 0 \\
Ambal & 43,50 & 4,02 & 30 & 70 & 55 & 35 & 10 & 0 \\
Mirit & 51,20 & 7,1 & 30 & 70 & 50 & 20 & 20 & 0 \\
\hline Rataan & 49,51 & 8,06 & 41,81 & 58,19 & 52,92 & 28,58 & 16,00 & 0,83 \\
\hline
\end{tabular}

terlama sampai dengan yang paling baru yaitu 0,083 tahun dan yang terlama 30 tahun, hal ini menandakan bahwa usaha pasar rumput dari tahun ke tahun selalu bermunculan karena mudah dijalankan dan menguntungkan.

Pekerjaan sebagai penjual pasar rumput merupakan pekerjaan yang sudah cukup lama dijalankan oleh masyarakat Kabupaten Kebumen khususnya di Wilayah Pembibitan Sapi PO Kebumen. Usaha pasar rumput $41,81 \%$ dijadikan sebagai pekerjaan utama dan $58,19 \%$ dijadikan sebagai pekerjaan sampingan. Di Kecamatan Buluspesantren $80 \%$ responden menjadikan usaha pasar rumput sebagai pekerjan utama, karena dirasa menghasilkan keuntungan yang lebih besar dibandingkan pekerjaan sampingan yang dijalankan. Namun di lima kecamatan lainnya responden menjadikan usaha pasar rumput sebagai usaha sampingan, meskipun keuntungannya menjanjikan namun pekerjaan ini dianggap sebagai usaha yang tidak terlalu menyita waktu (dimulai siang sampai sore hari), sehingga pagi hari dapat digunakan untuk melakukan pekerjaan yang lain.

Pendidikan pelaku usaha pasar rumput sebagain besar merupakan lulusan SD $(52,92 \%)$ dan paling sedikit berpendidikan Sarjana $(0,83 \%)$. Pelaku usaha pasar rumput berpendapat bahwa pendidikan tinggi tidak terlalu dibutuhkan oleh pelaku usaha pasar rumput. Usaha pasar rumput merupakan usaha yang mudah dijalankan tanpa harus berpendidikan tinggi.

\section{Pasar Rumput}

Pasar rumput di wilayah pembibitan Sapi PO Kebumen berjumlah 126 pemilik pasar rumput (orang) yang tersebar di enam kecamatan (Tabel 2). Pasar merupakan tempat berkumpulnya sejumlah penjual dan pembeli dan terjadi transaksi jual beli dari barangbarang yang ada di sana (Arianty, 2019). Galuh (2011) menayatakan bahwa pasar dalam teori ekonomi adalah suatu situasi seseorang atau lebih pembeli (konsumen) dan penjual (produsen dan pedagang) melakukan transaksi setelah kedua belah pihak sepakat tentang harga terhadap sejuamlah (kuantitas) barang dengan kuantitas tertentu yang menjadi objek transaksi. Pasar rumput di wilayah pembibitan Sapi PO Kebumen merupakan tempat transaksi jual beli berbagai jenis pakan khususnya hijauan untuk kebutuhan ternak. Pasar menjadi sarana pertemuan antara penjual dan pembeli untuk melakukan transaksi pemenuhan barang yang dikehendaki. Bagi peternak sapi pakan yang sering dibeli atau dibutuhkan adalah jerami padi, rumput alam dan rumput gajah, sedangkan bagi peternak kambing lebih banyak membeli jerami kacang tanah.

Berdasarkan informasi pelaku usaha pasar rumput, usaha ini mulai muncul di awal tahun 90 'an. Awalnya pedagang rumput hanya mencari rumput untuk pakan ternak sendiri, namun lama-kelamaan beberapa peternak ada yang membeli karena tidak sempat mencari rumput. Selain itu lahan untuk mencari rumput di daerah pesisir pantai selatan Kabupaten 
Tabel 2 . Jumlah pemilik usaha pasar rumput

\begin{tabular}{lc}
\hline Kecamatan & Jumlah Pemilik Pasar Rumput (orang) \\
\hline Puring & 20 \\
Petanahan & 24 \\
Klirong & 32 \\
Buluspesantren & 20 \\
Ambal & 20 \\
Mirit & 10 \\
\hline Total & 126 \\
\hline
\end{tabular}

Kebumen mulai berkurang karena alih fungsi untuk perumahan warga. Karena usaha ini dirasa cukup menguntungkan dan mudah dijalankan sehingga sampai sekarang banyak yang mengikuti usaha menjual rumput.

Beberapa alasan usaha pasar rumput dijalankan oleh banyak pihak, terdapat 6 alasan yaitu:

1. Untuk menambah penghasilan

2. Usaha pasar rumput merupakan usaha yang menguntungkan

3. Banyaknya populasi ternak khususnya ternak sapi di Wilayah Pembibitan Sapi PO Kebumen

4. Membuka lapangan pekerjaan bagi orang lain

5. Bagi sebagian pelaku usaha pasar rumput yang menjalankan usaha ini sebagai usaha pokok, usaha pasar rumput menjadi sumber penghasilan untuk memenuhi kebutuhan sehari-hari

6. Usaha pasar rumput merupakan usaha yang mudah dijalankan dan tidak memerlukan pendidikan tinggi

Usahapasar rumput(48,30\%) dijalankan karena sebagai tambahan penghasilan. Seperti yang telah disampaikan sebelumnya bahwa $58,19 \%$ menyatakan bahwa usaha pasar rumput sebagai usaha sampingan, sehingga berfungsi sebagai penambah penghasilan dan bukan sebagai usaha pokok. Usaha pokok yang dijalankan diantaranya adalah tani, tukang, buruh, pegawai pemerintahan, dan pedagang.
Usaha pasar rumput merupakan usaha yang menguntungkan. Dari enam responden pelaku usaha pasar rumput di enam kecamatan Wilayah Pembibitan Sapi PO Kebumen menunjukan pendapatan yang cukup menjanjikan setiap harinya. Selain menguntungkan, usaha pasar rumput banyak dijalankan karena populasi ternak bertambah, sehingga konsumen rumput akan selalu ada. Purwawangsa dan Bramada (2014) menyatakan bahwa peningkatan jumlah populasi dan teknikbudidaya sapi dalam rangka swadaya dengansendirinya akan meningkatkan kebutuhan HPT.

Berdasarkan data Kebumen Dalam Angka Tahun 2018, sebanyak 65.713 ekor sapi potong yang tersebar di 26 kecamatan, 37.172 $(56,57 \%)$ ekor terdapat di enam kecamatan wilayah pembibitan Sapi PO Kebumen. Berdasarkan hasil penelitian Sugiarto et al. (2017), Peternak Sapi PO Kebumen memiliki rataan kepemilikan ternak sebanyak 1,98 Satuan Ternak (ST). Berdasarkan jumlah kepemilikan ternak, jumlah peternak di Wilayah Pembibitan Sapi PO Kebumen sebanyak 18.773 peternak. Peternak ini merupakan konsumen potensial pasar rumput.

Usaha pasar rumput juga menjadi suatu lapangan kerja baru bagi beberapa orang. Yang terlibat dalam usaha pasar rumput tidak hanya pemiliknya saja, namun terdapat pihak lain yang perannya sangat penting yaitu pemasok pakan ke pasar rumput. Sebagian besar pasar rumput mendapatkan rumput dari pemasok, sedangkan sebagian kecil yang mencari rumput sendiri. Pensuplay pakan 


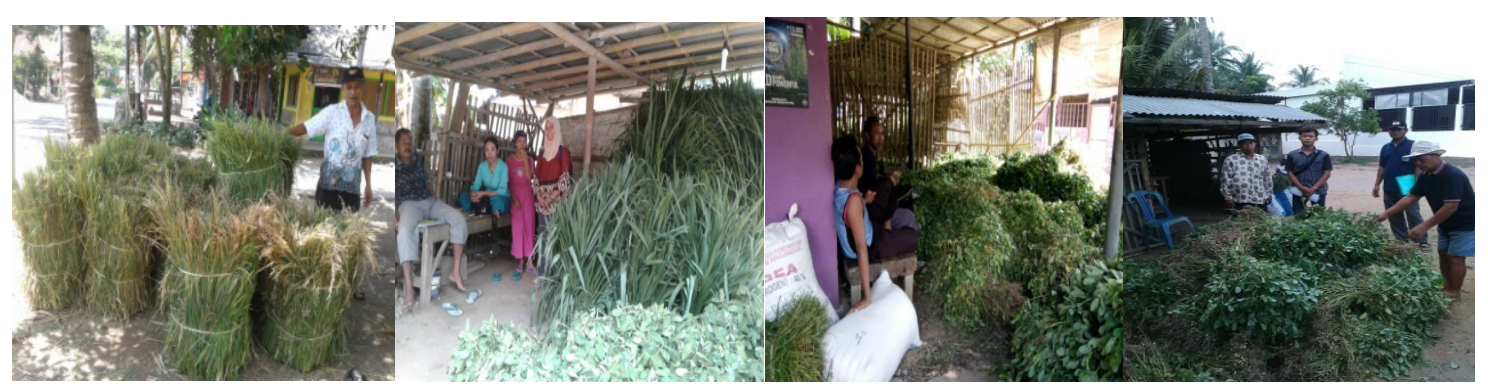

Gambar 1. Pasar Rumput

pun berbeda-beda setiap komoditasnya, pemasok jerami akan berbeda dengan pemasok rumput gajah dan yang lainnya. Setiap pasar rumput telah memiliki pemasok pakan langganan, meskipun tidak terdapat perjanjian yang mengikat. Di lima kecamatan (Puring, Petanahan, Klirong, Buluspesanten, dan Ambal), pemasok pasar rumput bersaing harga dan bebas menentukan mau memasok ke pasar rumput mana saja meskipun sudah langganan. Namun terdapat keunikan di Kecamatan Mirit, dimana pemasok hanya akan mengirim rumput ke pasar rumput langganannya saja dengan harga yang lebih stabil. Contoh kondisi pasar rumput dapat dilihat pada Gambar 1.

Belum banyak yang mengkaji tentang pasar rumput. Pasar rumput dapat dikategorikan kedalam jenis pasar tradisional. Tempat berjualan yang menggunakan bangunan sangat sederhana bahkan terdapat juga yang berjualan di ruangan terbuka. Kotler (2001) menyatakan bahwa pasar tradisional merupakan tempat bertemunya penjual dan pembeli yang ditandai dengan adanya transaksi secara langsung dan biasanya disertai proses tawar-menawar, bangunan pasar biasanya terdiri dari kios-kios atau gerai, los dan dasaran terbuka yang dibuka oleh penjual maupun suatu pengelola pasar.

\section{Jenis Pakan yang Dijual di Pasar Rumput}

Jenis pakan yang diperjualbelikan oleh pelaku pasar rumput terdiri atas tujuh jenis pakan yaitu : jerami padi, rumput alam, rumput gajah, rumput gajah odot, jerami kacang tanah (rendeng), kangkung dan dedak, dapat dilihat pada Gambar 2. Namun tidak semua pasar rumput menjual ketujuh komoditas pakan tersebut. Ada yang hanya menjual satu jenis saja dan yang paling lengkap menjual seluruh jenis pakan tersebut. Pasar rumput yang menjual tujuh jenis pakan lengkap terdapat di Kecamatan Puring. Pasar rumput ini memang cukup besar dengan komoditas jenis pakan yang lengkap. Apabila pasar rumput pada umumnya mulai menjual rumput di siang hari pasar rumput yang satu ini sudah menjual pakan dari pagi hari.

Jenis pakan yang paling banyak dijual oleh pelaku usaha pasar rumput adalah jerami padi. Dari 126 pasar rumput, 118 (92,19\%) pasar rumput menjual jerami padi dan hanya $8(7,81 \%)$ pasar rumput yang tidak menjual jerami padi. Jerami padi merupakan pakan utama ternak Sapi PO Kebumen di Kabupaten Kebumen. Hidayat et al. (2016) pakan yang umum diberikan oleh peternak Sapi PO Kebumen adalah jerami padi.

\section{Analisis Usaha Pasar Rumput}

Perhitungan analisa usaha dilakukan pada pasar rumput yang paling besar atau paling banyak jumlah komoditas pakan yang dijual di masing-masing kecamatan. Perhitungan terdiri dari biaya, penerimaan, pendapatan/laba dan NMP (dapat dilihat pada Tabel 3). Komponen biaya pada usaha pasar rumput terdiri dari modal pembelian komoditas pakan, biaya BBM, biaya penyusutan bangunan, biaya tenaga kerja, biaya penyusutan kendaraan dan biaya sewa tempat. Komponen biaya paling besar adalah modal pembelian rumput per hari nya. Masing-masing pasar rumput berbeda sesuai dengan jumlah komoditas pakan yang dijual. Rata-rata biaya yang dikeluarkan pasar rumput per hari adalah Rp. 2,580,362.82. 

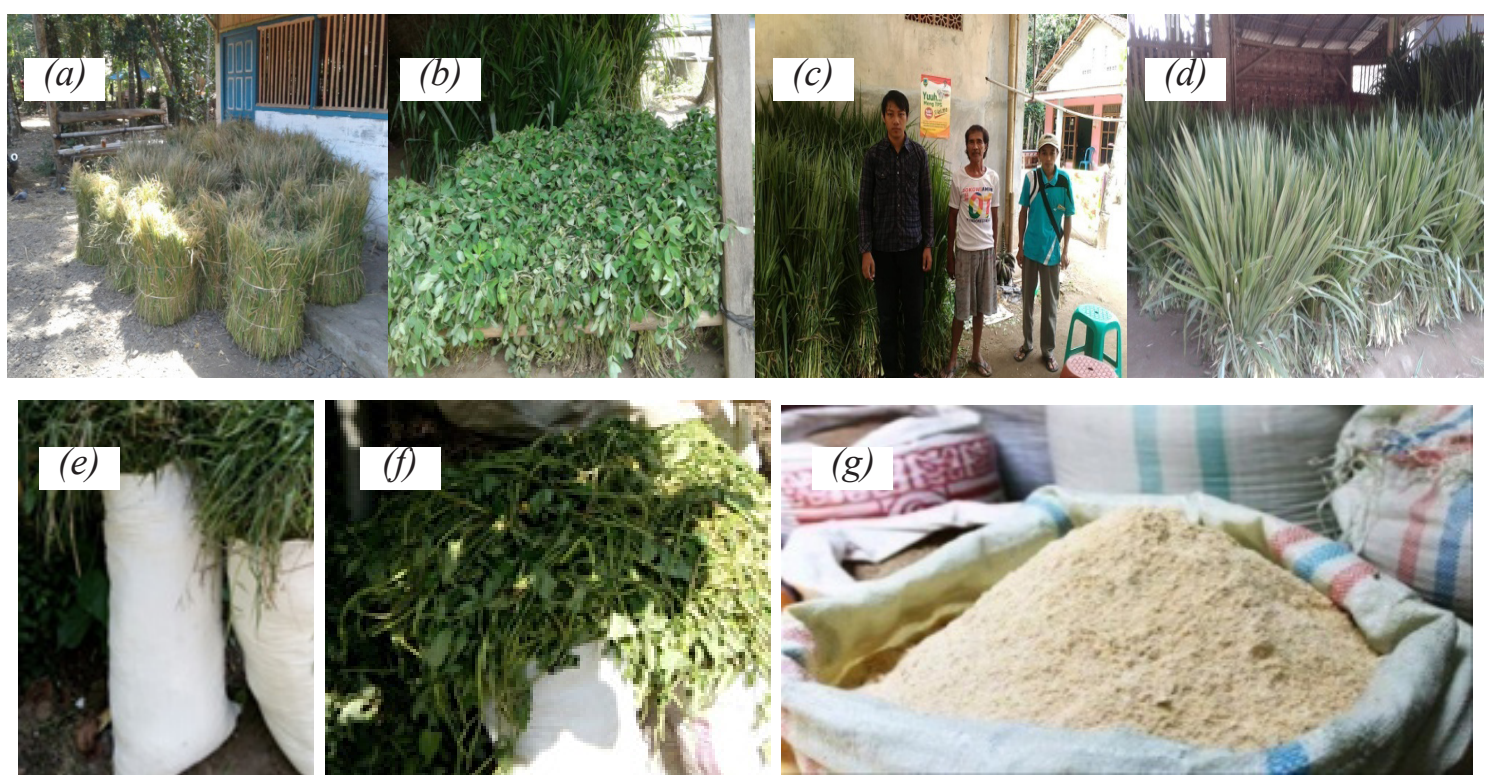

Keterangan: (a) Jerami Padi, (b) Jerami Kacang Tanah (rendeng), (c) Rumput Gajah, (d) Rumput Gajah Odot, (e) Rumput alam, (f) Kangkung, dan (g) Dedak Padi

Penerimaan adalah jumlah produksi yang dihasilkan dalam suatu kegiatan usaha dikalikan dengan harga jual yang berlaku di pasar. Penerimaan pada usaha pasar rumput terdiri dari penjualan komoditas pakan pada hari itu terjual dan penjualan sisa pakan di hari berikutnya dengan harga $50 \%$ lebih rendah dari harga jual aslinya. Penerimaan yang diperoleh usaha pasar rumput berbedabeda tergantung dari jumlah komoditas pakan yang dijual dan keuntungan yang diambil dari setiap komoditas pakan yang dijual. Keuntungan yang diambil dari setiap komoditas pakan berbeda-beda pada setiap kecamatan. Keuntungan yang diambil dari komoditas rumput gajah dan rumput gajah odot/ikat berkisar anatara Rp. 1.500,00 sampai dengan Rp. 2.000,00, keuntungan jerami kacang tanah/ikat antara Rp. 750,00 sampai dengan Rp.3.000,00.

Keuntungan jerami kacang tanah cukup signifikan karena ketersediannya yang tidak menentu dan pemasok yang tidak tetap. Keuntungan jerami per ikat antara Rp. $1.500,00$ sampai dengan Rp. 2.000,00 dan keuntungan rumput alam per ikat Rp. 1.500,00 sampai dengan Rp. 3.750,00 kangkung, dan dedak hanya dijual oleh beberapa pelaku usaha pasar rumput dengan kisaran keuntungan $\mathrm{Rp}$. 2.500,00/ikat dan Rp.200,00/kg.

Rata-rata penerimaan per hari usaha pasar rumput di enam kecamatan wilayah pembibitan Sapi PO Kebumen adalah Rp. 2.998.473,21, dan keuntungan bersih Rp.418.110,39/hari. Apabila diakumulasikan dalam satu bulan, pendapatan pelaku usaha pasar rumput berkisar antara Rp.6.169.212, 30 sampai dengan $23.491 .952,10$ per bulan. Angka ini jauh lebih besar dibandingkan angka UMK Kabupaten Kebumen (Disnaker Jateng, 2018) yang hanya sebesar Rp. 1.686.000,00/bulan. Angka pendapatan atau keuntungan ini juga jauh lebih besar dibandingan dengan pendapatan menjalankan usaha penanaman rumput gajah yang berkisar antara Rp 2.646.958,- sampai dengan Rp 3.635.208,- (Makhmudi, 2015). Berdasarkan hasil penelitian Prasetyo (2004) menyatakan bahwa usaha penanaman rumput gajah sistem tebasan dalam satuhektar pengelola lahan rumput memperolehkeuntungan bersih sebanyak Rp.18.540.000,-/tahun dan sistem penjualan per ikat rumput berkisar seberat 50 kg dengan harga Rp. 5.000/ikat pada musim 
Tabel 3. Analisis usaha pasar rumput

\begin{tabular}{lcccc}
\hline Kecamatan & $\begin{array}{c}\text { Penerimaan } \\
(\mathrm{Rp} / \mathrm{hari})\end{array}$ & Biaya (Rp/hari) & $\begin{array}{c}\text { Pendapatan/ } \\
\text { Profit (Rp/hari) }\end{array}$ & $\begin{array}{c}\text { Net Profit Margin } \\
(\mathrm{NPM})(\%)\end{array}$ \\
\hline Puring & $2.423 .464,29$ & $2.200 .571,92$ & $222.892,37$ & 9,20 \\
Petanahan & $1.680 .000,00$ & $1.400 .821,92$ & $279.178,08$ & 16,62 \\
Klirong & $5.590 .000,00$ & $4.806 .934,93$ & $783.065,07$ & 14,01 \\
Buluspesantren & $1.961 .000,00$ & $1.508 .321,92$ & $452.678,08$ & 15,46 \\
Ambal & $2.814 .500,00$ & $2.608 .859,59$ & $205.640,41$ & 7,31 \\
Mirit & $3.521 .875,00$ & $2.956 .666,67$ & $565.208,33$ & 16,05 \\
\hline Rataan & $2.998 .473,21$ & $2.580 .362,82$ & $418.110,39$ & 13,11 \\
\hline
\end{tabular}

kemarau dan Rp. 2.500/ikat pada musim penghujan dapat diperoleh keuntungan bersih sebanyak Rp. 7.540.000/tahun. Pendapatan dari usaha pasar rumput dapat disimpulkan lebih tinggi, lebih mudah serta lebih singkat dalam mendapatkannya. Sehingga setiap tahunnya selalu bermunculan pelaku usaha pasar rumput baru yang mencari rejeki di bidang penjualan pakan ternak ini.

Berdasarkan perhitungan pendapatan tersebut, jelas seluruh pelaku usaha pasar rumput menyatakan bahwa usaha ini menguntungkan dan mampu memenuhi kebutuhan finansial pelaku usahanya. Umar (2007) menyatakan bahwa proses bisnis dikatakan sehat dari sisi keuangan apabila mampu memenuhi kewajiban finansialnya dan memberikan keuntungan yang layak.

Darsono dan Ashari (2005) menyatakan bahwa Rasio Net Profit Margin disebut juga dengan rasio pendapatan terhadap penjualan. Angka NPM usaha penjualan pasar rumput berkisar antara 9,20\% sampai dengan $16,62 \%$, dengan rata-rata $13,11 \%$. Angka NPM usaha psar rumput di wilayah pembibitan Sapi PO Kebumen termasuk ideal, dimana menurut Sulistyanto angka NPM dapat dikatakan baik apabila $>5 \%$. Semakin besar rasio NPM, maka dianggap semakin baik kemampuan sebuah usaha untuk mendapatkan laba yang tinggi. Hasil dari perhitungan mencerminkan keuntungan netto per rupiah penjualan. Angka rata-rata NPM 13,11\% memiliki arti bahwa pada usaha pasar rumput, setiap penjualan komoditas pakan Rp. 1,00 akan mendapatkan keuntungan sebesar Rp. 0,1311. Bastian dan Suhardjono (2006) menyatakan bahwa Net Profit Margin (NPM) adalah perbandingan antara laba bersih dengan penjualan. Semakin besar nilai NPM, maka kinerja perusahaan akan semakin produktif, sehingga dapat meningkatkan kepercayaan investor untuk menanamkan modalnya pada perusahaan tersebut. Informasi lain dijelaskan oleh Harahap (2007) yang menyatakan bahwa semakin besar rasio NPM makan akan semakin baik karena dengan demikian perusahaan memperoleh laba yang cukup tinggi. Angka NPM usaha pasar rumput yang ideal, menandakan bahwa usaha ini menguntungkan dan sangat memungkinkan para investor untuk menanamkan modalnya pada usaha pasar rumput di wilayah pembibitan Sapi PO Kebumen. Berdasarkan aspek sosial usaha pasar rumput tidak mengganggu lingkungan dan dianggap menolong peternak dalam penyediaan pakan. Berdasarkan Nurmalina et al. (2009) menyatakan bahwa suatu usaha tidak akan ditolak oleh masyarakat sekitar apabila dari aspek sosial budaya diterima dan secara ekonomi memberikan kesejahteraan.

\section{KESIMPULAN}

1. Jumlah pelaku usaha pasar rumput di Wilayah Pembibitan Sapi PO Kebumen adalah 126 pelaku usaha pasar rumput.

2. Komoditas pakan yang diperjualbelikan di pasar rumputterdiri dari jerami padi, rumputgajah, rumput gajah odot, jerami 
kacang tanah (rendeng), rumput alam, kangkung dan dedak.Komoditas yang paling banyak diperjualbelikan adalah jerami padi.

3. Rata-rata pendapatan pelaku (pedagang) usaha pasar rumputdi Wilayah Pembibitan Sapi PO Kebumen sebesar Rp.418,110.39/hari. Sedangkan Nilai rata-rata NPM usaha pasar rumput adalah sebesar $13.11 \%$.

\section{DAFTAR PUSTAKA}

Alexandri. 2008. Manajemen Keuangan Bisnis. Cetakan kesatu. Alfabeta, Bandung.

Arianty, N. 2013. Analisis Perbedaan Pasar Modern Dan Pasar Tradisional Ditinjau Dari Strategi Tata Letak (Lay Out) Dan Kualitas Pelayanan Untuk Meningkatkan Posisi Tawar Pasar Tradisional. Jurnal Manajemen \& Bisnis. Vol 13 No. 01 April 2013 Issn 1693-7619.

Bastian, Indra dan Suhardjono. 2006. Akuntansi Perbankan. Edisi 1. Jakarta: Salemba Empat.

BPS Kabupaten Kebumen. 2018. Kabupaten Kebumen dalam Angka. BPS Kabupaten Kebumen. Puspita Warna.

Darsono dan Ashari. 2005. Pedoman Praktis Memahami Laporan Keuangan. Jakarta. Salemba Empat.

Dinas Tenaga Kerja, Transmigrasi, dan Kependudukan (Disnakertransduk) Jateng. 2019. Ini Daftar UMK 2019 di 35 Kabupaten/Kota di Jateng. Diakses dari:https://m.solopos.com/semarang/ $\mathrm{red} / 20181122 / 515 / 954372 /$ in i daftarumk-2019-di-35-kabupatenkotadjateng. Pada 02 September 2019.

Galuh, O. 2011. Redesain Pasar Tradisional Jongke Surakarta. Universitas Atma Jaya. Yogyakarta.

Harahap, Sofyan Syahfri. 2007. Analisis Kritis atas Laporan Keuangan. PT. Raja
Grafindo Persada. Jakarta.

Hidayat, R., A. Zabiq., M. F. Ridho., M. Yuniarti, dan D. Samsudewa. 2016. Peran Mahasiswa Dalam Pendampingan Penguatan Pakan Induk Sapi Potong Di Kabupaten Kebumen. Jurnal INFO. Edisi XVIII. Nomor 3. Oktober 2016.

Kotler, P. 2001. Manajemen Pemasaran: Analisis, Perencanaan, Implementasi, dan Kontrol. PT Prehallindo. Jakarta.

Makhmudi, M. 2015. Analisis Pendapatan Dan Kelayakan Usaha Budidaya Rumput Gajah Melalui Rehabilitasi Kesuburan Tanah. Sekolah Tinggi Penyuluhan Pertanian (STTP). Bogor.

Nurmalina, R., Sarianti, T. dan Karyadi, A. 2009. Studi Kelayakan Bisnis. Bogor: Departemen Agribisnis Fakultas Ekonomi dan Manajemen Institut Pertanian Bogor.

Nuraeni dan Aryadi. 2017. Studi Kelayakan Pengelolaan Usaha Pembibitan \& Penggemukan Sapi PO Kebumen. Dalam Proseeding Inovasi \& Kreasi Memajukan Jawa Tengah14-15 Desember 2017. Bappeda Provinsi Jawa Tengah. ISBN: 978-602-8916-332.

Prasetyo, A. 2004. Model Usaha Rumput Gajah Sebagai Pakan SapiPerah Di Kecamatan Getasan, Kabupaten Semarang. Lokakarya Nasional Tanaman Pakan Ternak. Balai Pengkajian Teknologi Pertanian Jawa Tengah.

Purwawangsa, H. dan B. W. Putera. 2014. Pemanfaatan Lahan Tidur Untuk Penggemukan Sapi. Jurnal Risalah Kebijakan Pertanian Dan Lingkungan. Vol. 1 No. 2, Agustus 2014: 92-96. ISSN: 2355-6226.

Sinurat, A.P. 2001. Pemanfaatan Bahan Pakan Lokal. Makalah pada Dies Natalis HIMASITER III Fakultas Peternakan IPB, Bogor.

Soedardjat, S. 2001. Dukungan Pemerintah 
terhadap Keberadaan Bahan Baku Pakan Lokal. Makalah pada Dies Natalis HIMASITER III Fakultas. Peternakan Institut Pertanian Bogor, Bogor.

Sudrajad, P dan Subiharta. 2013. Phenotypic Characteristics of Ongole Grade Cows in Kebumen. Dalam Seminar Nasional Teknologi Peternakan dan Veteriner 2013. Balai Pengkajian Teknologi Pertanian Jawa Tengah. Halaman 98106.

Sugiarto, M., S. Nur, dan O. E. Djatmiko. 2017. Optimalisasi Curahan Waktu Kerja DanPenambahan Skala Usaha Perbibitan Sapi PO Kebumen. Dalam Prosiding Seminar Nasional Dan Call For Papers "Pengembangan Sumber Daya Perdesaan Dan Kearifan Lokal Berkelanjutan Vii” 17-18 November
2017. Fakultas Peternakan UNSOED, Purwokerto.

Suwardjono. 2008. Teori Akuntansi, Pelaporan Keuangan, Lokakarya Nasional Tanaman Pakan Ternak. BPFE, Yogyakarta.

Tabrany, H., L. A. Sofyan., E. B. Lacony, dan A. Daryanto. 2004. Potensi Sumber Daya Pakan Di Wilayah Provinsi Jawa Tengah. J. Indon Trop Anim Agric. 29 (1) March 2004.

Umar, H. 2007. Studi Kelayakan Bisnis Teknik Menganalisis Kelayakan RencanaBisnis Secara Komprehensif. Jakarta: Gramedia Pustaka Utama.

Undang-Undang Republik Indonesia Nomor 13 Tahun 2003. Tentang Ketenagakerjaan. Lembaran Negara Republik Indonesia Tahun 2003 Nomor 39. 